\title{
First evidences for induced pseudo-viviparous germination in Ageratina adenophora (Crofton weed), a common alien weed of Darjeeling Himalaya, India
}

\author{
Narayan C. Karmakar ${ }^{1^{*}}$ and Anjan Hazra ${ }^{2}$ \\ ${ }^{1}$ Post Graduate Department of Botany, Barasat Government College, 10 K N C Road, Barasat, Kolkata - 700124, West Bengal, India \\ ${ }^{2}$ Agricultural and Ecological Research Unit, Indian Statistical Institute, Kolkata - 700108, India
}

Article history

Received: 13 April 2016

Accepted: 6 June 2016

Published: 1 July 2016

(C) Karmakar and Hazra (2016)

Editor

K K Sabu

Publisher

Horizon e-Publishing Group

Corresponding Author

Narayan C. Karmakar

凶nckarmakarbot@gmail.com

\begin{abstract}
In the present investigation, an autecological study has been carried out for Ageratina adenophora (Spreng.) R.M. King \& H. Rob., a common aggressive alien weed found in dense patches at different localities of Darjeeling Himalaya, West Bengal, India. Single generation colony, derived via induced pseudo-viviparous germination, outnumbers the associated species by its aggressiveness and allelopathic potentiality. The cypselae (fruits) mature during full monsoon and being laden with water droplets shed their deciduous calyx (pappus). The later thus cannot disperse away from the head (capitulum) by effective parachute mechanism. Very frequently, many of the cypselae get germinated with two minute paracotyledons on the receptacle that still attached with the mother plant by decaying receptacle stalk. Entire head with cluster of seedlings, becoming heavy by monsoon shower, drops down on the lower wet substratum. It is the beginning of the colony formation. Vigorous growth and allelopathic potentiality of the species decreases the establishment, growth and density of other plant species in that area facilitating procurement of more space and nutrients for the individuals by itself, leading to make a dense colony with very high Importance Value Index (IVI). All these features may be considered as an adaptation to maintain its invasiveness and dominance over the surrounding species.
\end{abstract}

Keywords

Ageratina adenophora; invasive plants; pseudo-vivipary; allelopathy; Importance Value Index (IVI)

Karmakar, N. C. and A. Hazra. 2016. First evidences for induced pseudoviviparous germination in Ageratina adenophora (Crofton weed), a common alien weed of Darjeeling Himalaya, India. Plant Science Today 3(3): 249-257. http://dx.doi.org/10.14719/pst.2016.3.3.234

\section{Introduction}

Ageratina adenophora (Spreng.) R.M. King \& H. Rob., also known as Eupatorium adenophorum Spreng. (1826), belongs to the family Asteraceae. The plant is commonly known as crofton weed or sticky eupatorium, being other local common names as sticky snakeroot, Mexican devil, and cypress weed in USA, New Zealand and India, respectively. It is native to central Mexico and thereby introduced in many other countries as an ornamental plant. Subsequently, this new comer has established and spread over the regions and became an invasive species. Ageratina adenophora was introduced in India after 1498 (Biswas, 1934). At present, it is an important alien species in Indian flora. The plant rated as class-iv noxious weed under NSW (New South Wales) noxious weed act, 1993. 
Ageratina adenophora is a perennial under shrub, growing up to about 1-2 meters with opposite trowel-shaped serrate leaves $(6-10 \mathrm{~cm} \times 3$ $6 \mathrm{~cm}$ ) having three primary veins. Small creamy white composite flowers bloom in monsoon on characteristic capitulum (head) of $0.3 \mathrm{~cm}$ to $0.5 \mathrm{~cm}$ in diameter. The heads develop in terminal clusters to the branches. The fruits (cypsela) are small, with simple, deciduous pappus.

The name 'Crofton weed' is used for the species as it significantly contains essential oil in its aerial parts (Qu et al., 2011), and its dense patches over a large area prevent soil erosion (Baniya and Bhattarai, 1984). In the present work we noticed induced pseudo-vivipary and single generation colony formation, in addition to allelopathic potentiality leading to its aggressiveness and dominance.

Vivipary is a common reproductive feature of mangroves. Their seeds do not enter dormancy and germinate protruding their radicles whilst attached to the maternal plant. Some plants like members of the Rhizophoraceae show continuing embryo growth prior to dispersal, like vivipary. Here, embryo growth begins with the protrusion of a cotyledon body from the seed before dispersal. Radicle protrudes on the substratum only after shedding. The process is characterized as "semi-vivipary" (Ismail, 2010). Pseudo-vivipary is the feature of producing propagules like plantlets in an inflorescence, instead of seeds whether all other parts of the plant appear normal (Elmqvist and Cox, 1996). This interesting feature mostly induced by habitat condition and vary with area to area, species to species or season to season (Gordon-Gray et al., 2009), as previously reported in some members belonging to Cyperaceae (Gordon-Gray et al., 2009) and Poaceae (Vega and Rugolo-de-Agrasar, 2006; Milton et al., 2008; Kuzmanović et al., 2012).

Among the Eastern Himalayan angiosperms, vivipary has been reported in very few species that include Sechium edule (Jacq.) Sw. (chayote) of Cucurbitaceae (Aung et al., 1990), and Trifolium repens L. (white clover) of Fabaceae (Majumdar et al., 2004). Like vivipary, 'pseudovivipary' is a mode of ecophysiological adaptation, developing a continue reproduction to escape dormancy for the establishment of new generation in their prevailing habitat with excessively wet or saline marshy soil. In the present work the characteristic of pseudo-vivipary has been found in the non-mangrove plant A. adenophora of Asteraceae as an adaptive advanced reproductive trait for aggressiveness via single colony formation that may be useful for greater possibilities of survival and dominance of the species.

Some plants exert allelopathic influence (Gawronska et al., 2006; Inderjit et al., 2003; Putnam et al., 1978; Reigosa et al., 2006) by secreting a number of secondary metabolites which have inhibitory effect on the growth and development of other plants, microorganisms and animals (Calera et al., 1995). Such allelopathic potentiality has been reported in A. adenophora by Rai and Tripathi in 1981 together with many other researchers thereafter.

In the present work, allelopathic potentiality of the species has been studied in connection with the quantitative analysis of $A$. adenophora dominated discrete plant communities by quadrat method. High density of the species in an area enhances the concentration of the released allelochemicals that in turn enhances the elimination of non-self-species individuals.

\section{Materials and Methods \\ Relative dominance study by community analysis}

The present autecological study on $A$. adenophora has been carried out at different altitudinal zones of the Eastern Himalayan hill station Darjeeling (2,042 $\mathrm{m}$ AMSL) and its adjoining areas like Tiger hill (2,590 m AMSL), Lebong (1,661 m AMSL), Kalimpong (1,250 m AMSL), Lava (2,138 m AMSL), Rishop (2,138 m AMSL) and Neora valley (2,360 m AMSL) during monsoon and long post monsoon seasons. Observations were continued through successive five years (July 2010 to June 2015). The localities of study include roadsides, forest boundaries, and undisturbed slopes of hills among others. The annual mean temperature of the regions with cold temperate climate varied between $5^{\circ} \mathrm{C}$ to $16.5^{\circ} \mathrm{C}$ and the average annual precipitation is about $309.2 \mathrm{~cm}$. During monsoon (June to August) average temperature ranged between $13^{\circ} \mathrm{C}$ to $19^{\circ} \mathrm{C}$. It rained increasingly and the weather remained foggy or misty for most of the times. This was the period when humidity in Darjeeling was at its highest levels and it ranged between $93-96 \%$ of saturation. Average numbers of rain fall and rainy days during monsoon months in Darjeeling are June $2.06 \mathrm{~cm}$ (24.1 days), July $2.5 \mathrm{~cm}$ (32.0 days) and August $2.44 \mathrm{~cm}$ (26.6 days).

Distribution and dominance of the plant in its community was analyzed following the quadrat method (Priestley, 1913) with some modifications. In the current investigation sampling was done from ten different areas of the above mentioned localities. Sampling spots were selected on the basis of croftonweed invasion and sizes of the sampling quadrats were determined as $40 \mathrm{~cm}$ x 40 $\mathrm{cm}$ following species area curve i.e. manageable minimum size of the sampling unit covering maximum number of species in the spots under study. At each study site, four sampling quadrats were laid down. Number and basal diameter of each individual of $A$. adenophora and its associated species were noted down. The collected data of the four quadrats of each study site were combined together for the convenience of calculation. The sampling quadrats Qi+Qii+Qiii+Qiv had been taken as Q1 for site 1 


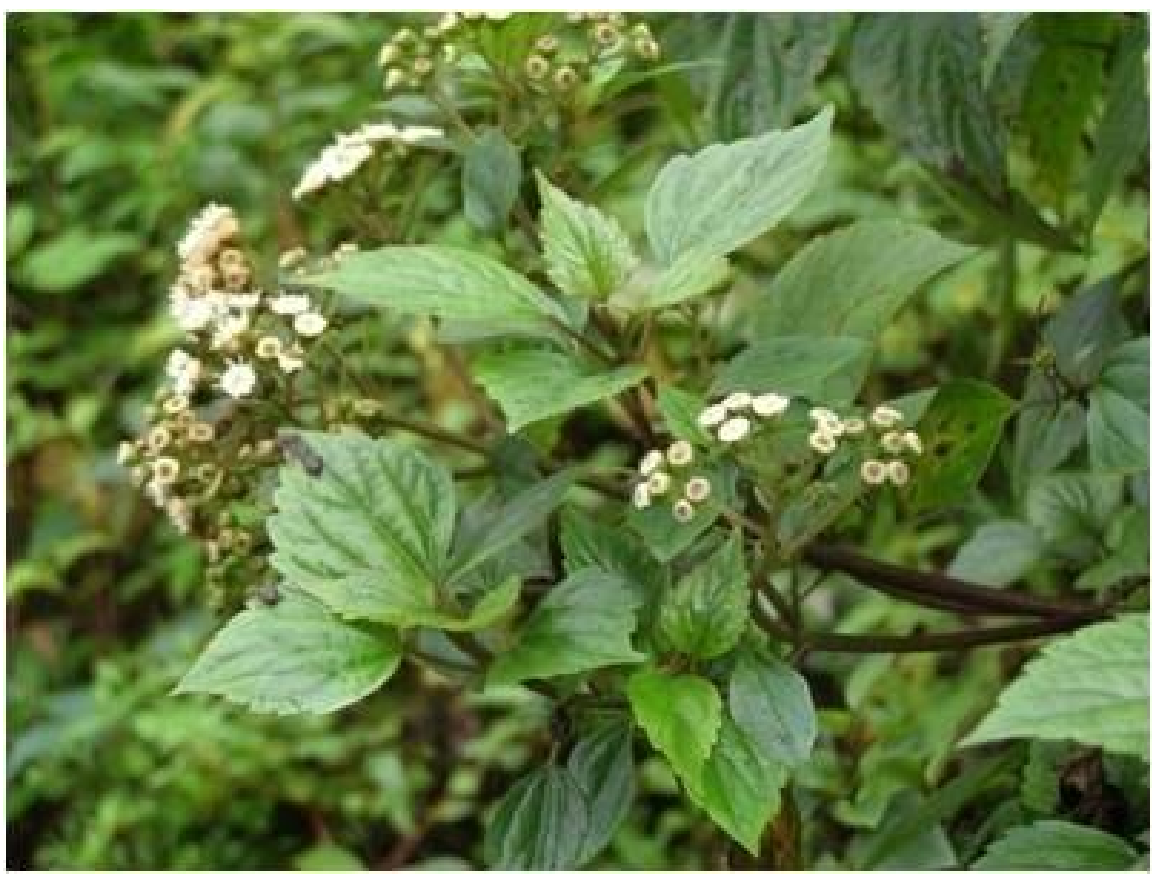

Figure 1: Image part of a flowering plant part of Ageratina adenophora (Spreng.) R.M. King \& H.Rob.

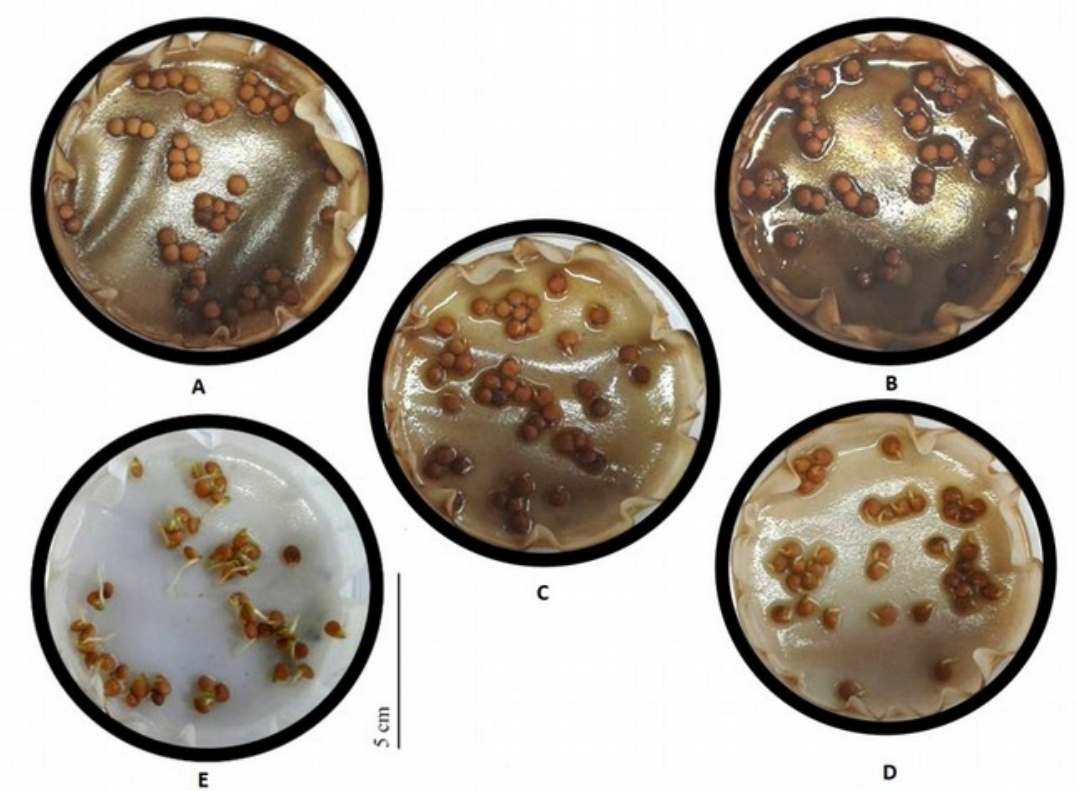

Figure 2: Allelopathic effect of varying concentrated tissue extract [A=1:5; $B=1: 10 ; C=1: 20$; and $D=1: 40$ (tissue extract: water, respectively) compared to $\mathrm{E}=\mathrm{Control]}$ on seed germination of lentil seeds

and followed accordingly up to Q10. From the field data of frequency, density, abundance, basal area, relative frequency, relative density, relative dominance, importance value index (IVI) and association index were calculated to have a quantitative structure of $A$. adenophora membered plant communities.

\section{Allelopathic potentiality}

In relevance of the work, an experiment on allelopathic potentiality of $A$. adenophora was carried out by using aqueous extract from the aerial parts on in vitro seed germination, and seedling growth inhibition of lentil (Lens culinaris Medik.), rice (Oryza sativa L.) and mustard (Brassica napus L.) seeds following the conventional method (Rai and Tripathi, 1981). Different concentration gradients of the plant extract were applied on the seeds under the experiment, and allowed to germinate on petri dishes with soaked blotting paper by maintaining moisture content. The biological assay was carried out in triplicate sets along with control sets. It was checked on regular basis in relation to the percentage of germination and the lengths of newly born radicle and plumule of the seedlings.

\section{Microscopic observation}

In the search of the structural specialty of the cypsela, microscopic studies from mature specimens were also carried out with the help of a binocular dissecting stereo microscope (Olympus). 
The process of imaging capitation of the cypsela and pappus was done with the aid of a digital camera (Olympus ST-500UZ).

\section{Observation of induced pseudo-viviparous germination and colony formation}

Pseudo-viviparous germination of the studied members have been evidenced by still photography captured during in vivo cypsela-seed germination that take place on the head receptacle still attached with mother plant and the subsequent formation of seedling colonies after falling on the lower substratum whatever on neighboring plant's leaf or the soil beneath.

\section{Collection and documentation of different stages of seedling development}

Seedlings with different stages of development (two para-cotyledons stage to eight leaves stages) were collected from the germinating seeds on the head as well as from the soil substratum. The collected seedlings were dried through paper pressing, mounted sequentially on herbarium sheets and photographed.

\section{Results and Discussion Community analysis}

The data collected from the studied areas by quadrat sampling, deliberately in $A$. adenophora (Figure 1) inhabited areas, shows its remarkably high dominance over other associated plant species (Table 1). In average, this species covered almost $3 / 4^{\text {th }}$ of its habitat itself. Among the 13 species found in the $A$. adenophora (relative frequency $28.57 \%$, see Table 1) dominant colonies the relative frequency (\%) was higher in case of Pilea umbrosa Bl. (14.28), Drymaria villosa Cham. \& Schltdl. (8.57) and Hypoestes triflora (Forssk.) Roem. \& Schult. (8.57) (Table 1). Similarly, importance value index (IVI) was highest in case of A. adenophora (198.38) among all members in the studied quadrats made a strong point to conclude the species as a notorious which dominate over the community and outnumbers the other members present in the colony where it belongs. Moreover, it was found that $A$. adenophora shows maximum association with $P$. umbrosa and a moderate level with $D$. villosa and $H$. triflora (see Table 1).

Invasive species are described by several aspects as they have been introduced by human activity into ecosystems where they are not native, and they have established populations of advantageous fast growing and self-reproducing, causing significant changes in pre-existing ecosystems (Richardson, 1994). Likewise, the increasing frequency, spatial patterns or scale of disturbances do lead to faster replacement of native species by exotic species (Yan et al., 2001). Massive invasion and spreading over colony is due to also typically allelopathic reasons (Chettri, 1986;
Rai and Tripathi, 1982). From field observation and all available information it is clear that $A$. adenophora follows the typical trends of an invasive weed. It mainly found in hilly temperate and subtropical areas that conforms to the statement that dominance of Ageratina species has occurred in transitional zones with adequate moisture (Kunwar, 2000). Invasive effect of this plant has become complex through variation in reproductive strategy and growth mode.

\section{Allelopathic potentiality}

Allelopathic potentiality test using aqueous extract of aerial parts of the weed showed significant effect on germination and seedling growth of three common field crops: lentil ( $L$. culinaris), rice (O. sativa) and mustard (B. napus) seeds (Table 2). It was observed that the lentil seed germination and growth of plumule and radicle was adversely affected (Figure 2). Germination was not started at all in the sets of concentrated plant extract (weed tissue and water proportion 1:5 and 1:10). After certain level of dilution, germination started but both the radicle and plumule growth were slow. The growth rate was gradually increased with further dilution of the extract and was maximum in case of control set that was devoid of the tissue extract. In case of rice and mustard germination was totally absent in presence of a minimum aqueous extract (result not shown). Up to six days of observation a single radicle was not found to be emerged from these two species seeds under the experiment in all replica sets except the control ones (result not shown).

From the experimental results it can be suggested that $A$. adenophora has sufficient potentiality to suppress growth of the cultivated crop species, also in addition to the wild herbs it dominate over colony. Same observation on another species was found and reported by Tripathi et al. (1981) where amongst the test species $T$. repens suffers the most. The different degree of effect by varying concentrated extract, inhibiting seed germination and the species specificity at suppression level, has been reflected in the present study and seems to be in congruence with the earlier report by Akhtar et al., 1978 and Whittaker et al., 1971. These effects are due to certain chemicals called allelochemics, generally found in the aerial parts of different plant species. After abscission of leaves and other parts of the plant falling under and around its canopy thereby decomposed and the chemicals incorporated into soil. Same action also occurred through rainfall which dissolves some amount of such chemicals from shoot canopy of the plant and mix into the soil. All these events ultimately increases the allelochemics in the underneath soil. Presence of this allelochemics affects the germination and growth of neighboring plants 


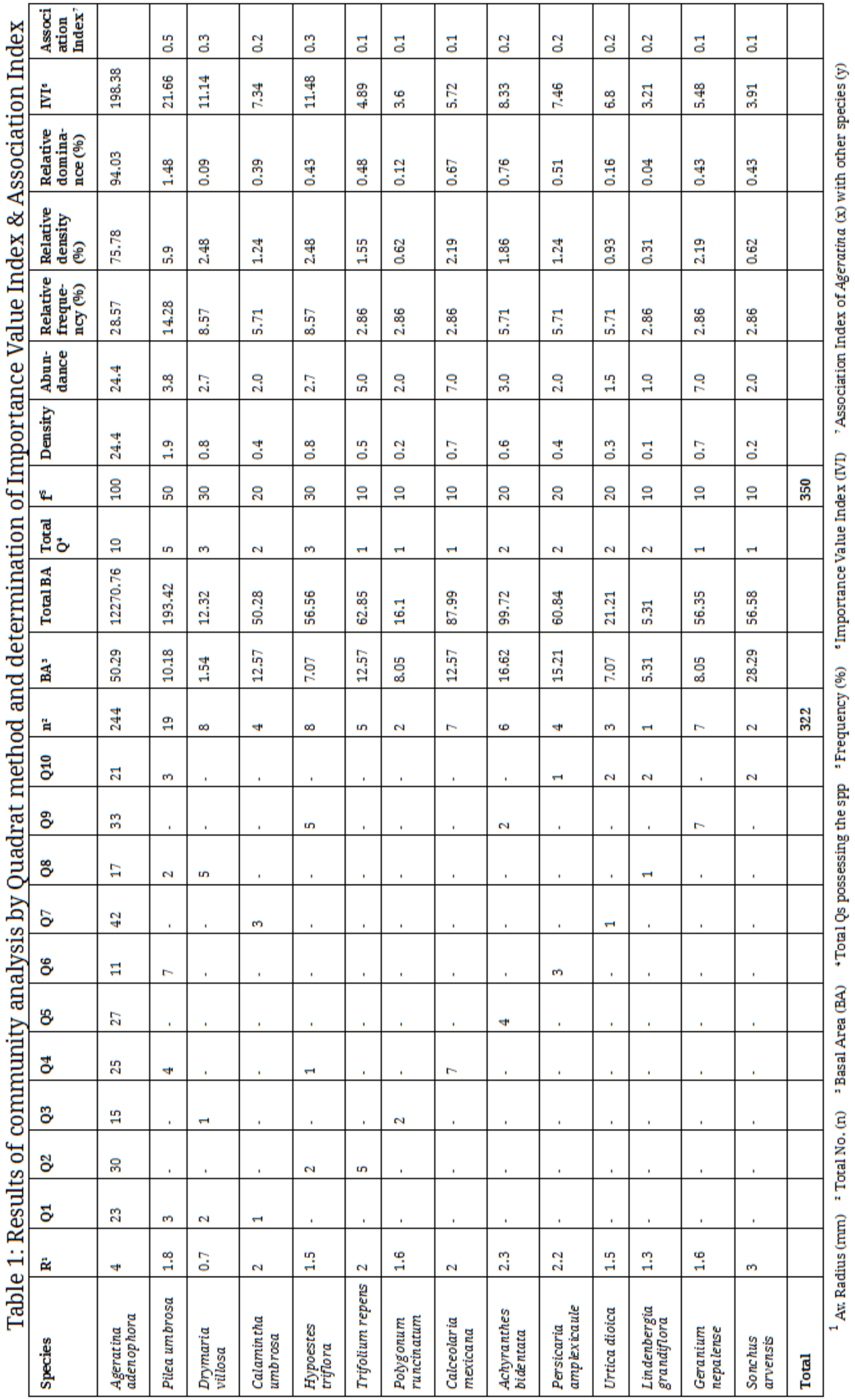




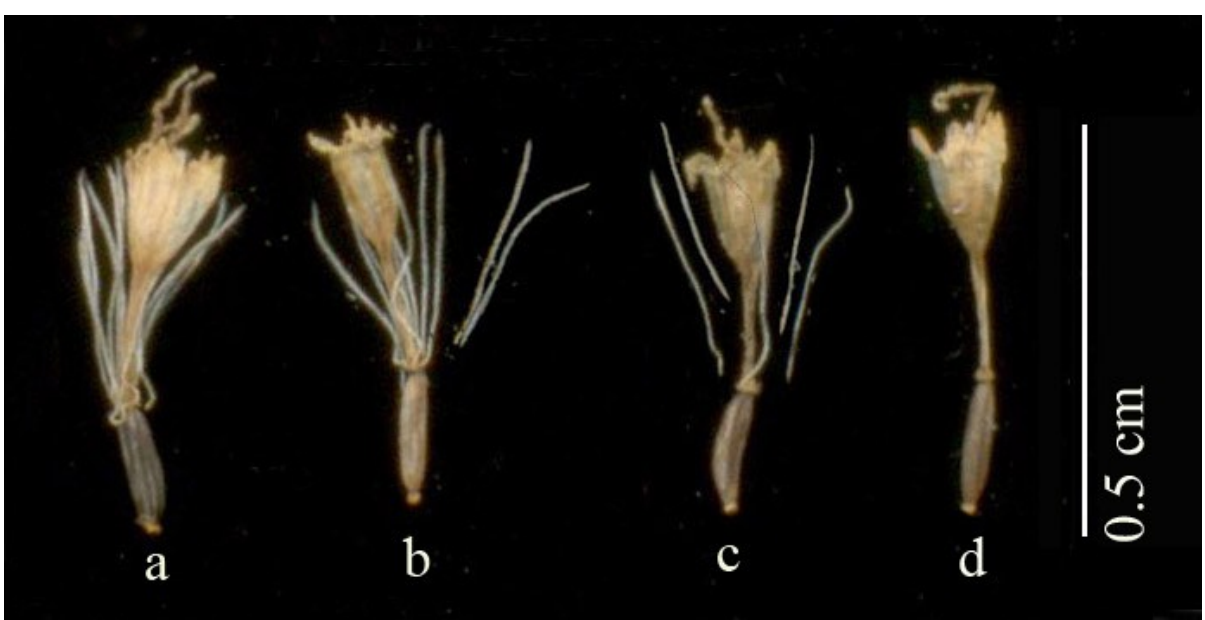

Figure 3: Cypsela under microscope with deciduous pappus showing different stages of shedding (a-d)

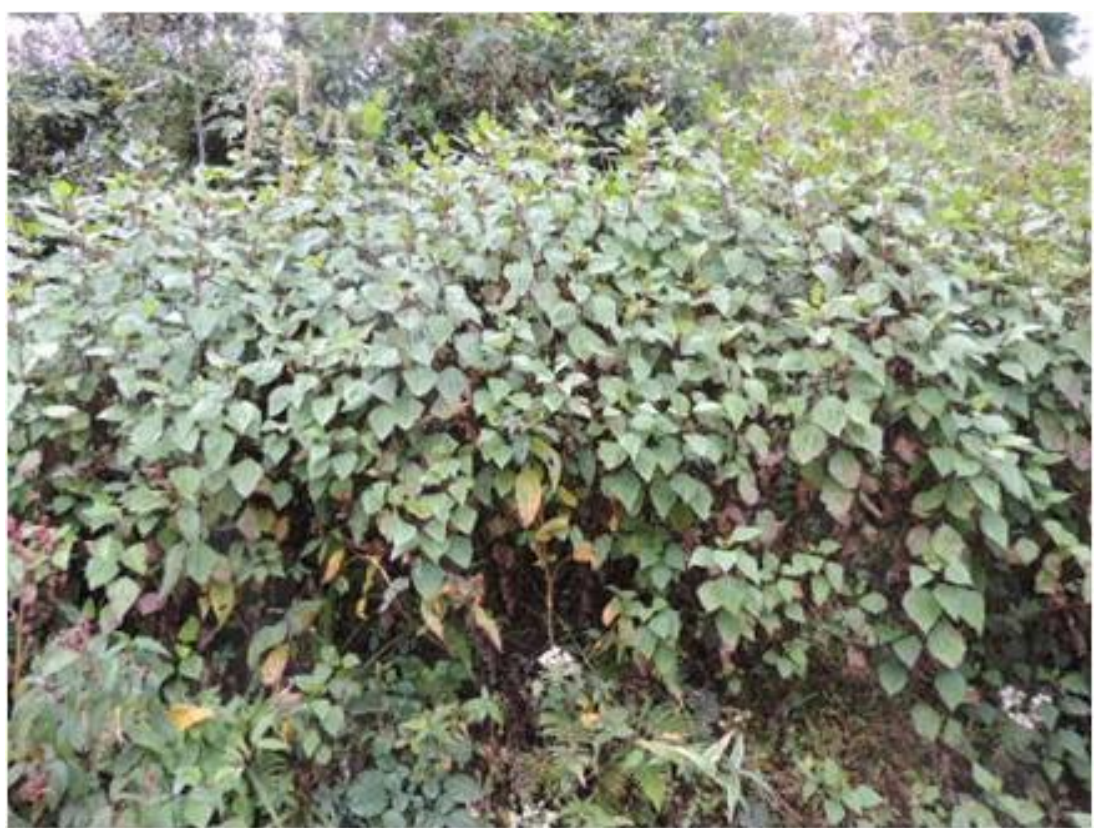

Figure 4: The single generation colony inhabited by Ageratina adenophora

Table 2: Allelopathic potentiality and seed germination inhibition

\begin{tabular}{llll}
\hline $\begin{array}{l}\text { Concentration of tissue } \\
\text { extract }\end{array}$ & $\begin{array}{l}\text { Length of growing radicle } \\
\text { and plumule at different } \\
\text { day interval }(\mathbf{c m})\end{array}$ & \\
\hline & $\mathbf{2}$ days & $\mathbf{4}$ days & $\mathbf{6}$ days \\
\hline Tissue:water & $\mathrm{R}: \mathrm{P}^{*}$ & $\mathrm{R}: \mathrm{P}$ & $\mathrm{R}: \mathrm{P}$ \\
\hline $1: 5$ & - & - & - \\
\hline $1: 10$ & - & - & - \\
\hline $1: 20$ & $0.2: 0.0$ & $0.5: 0.1$ & $0.8: 0.2$ \\
\hline $1: 40$ & $0.4: 0.0$ & $0.9: 0.2$ & $1.4: 0.3$ \\
\hline Control & $0.8: 0.2$ & $1.7: 0.4$ & $2.8: 1.2$ \\
\hline
\end{tabular}

*(R:P = Radicle:Plumule)

favouring the allelochemics containing plant to be forward in competition and dominate over colony.

\section{Deviated reproductive feature}

One common and unique characteristic of the Asteraceae family members is the presence of pappus (persistent modified calyx). After maturation of the flower it helps the cypsela (fruit type of Asteraceae) to migrate over places and maintain dispersal. In $A$. adenophora, the pappus was observed to dissociate from the cypsela when it matures (Figure 3). In this way, the mature cypsela with deciduous calyx cannot disperse by 


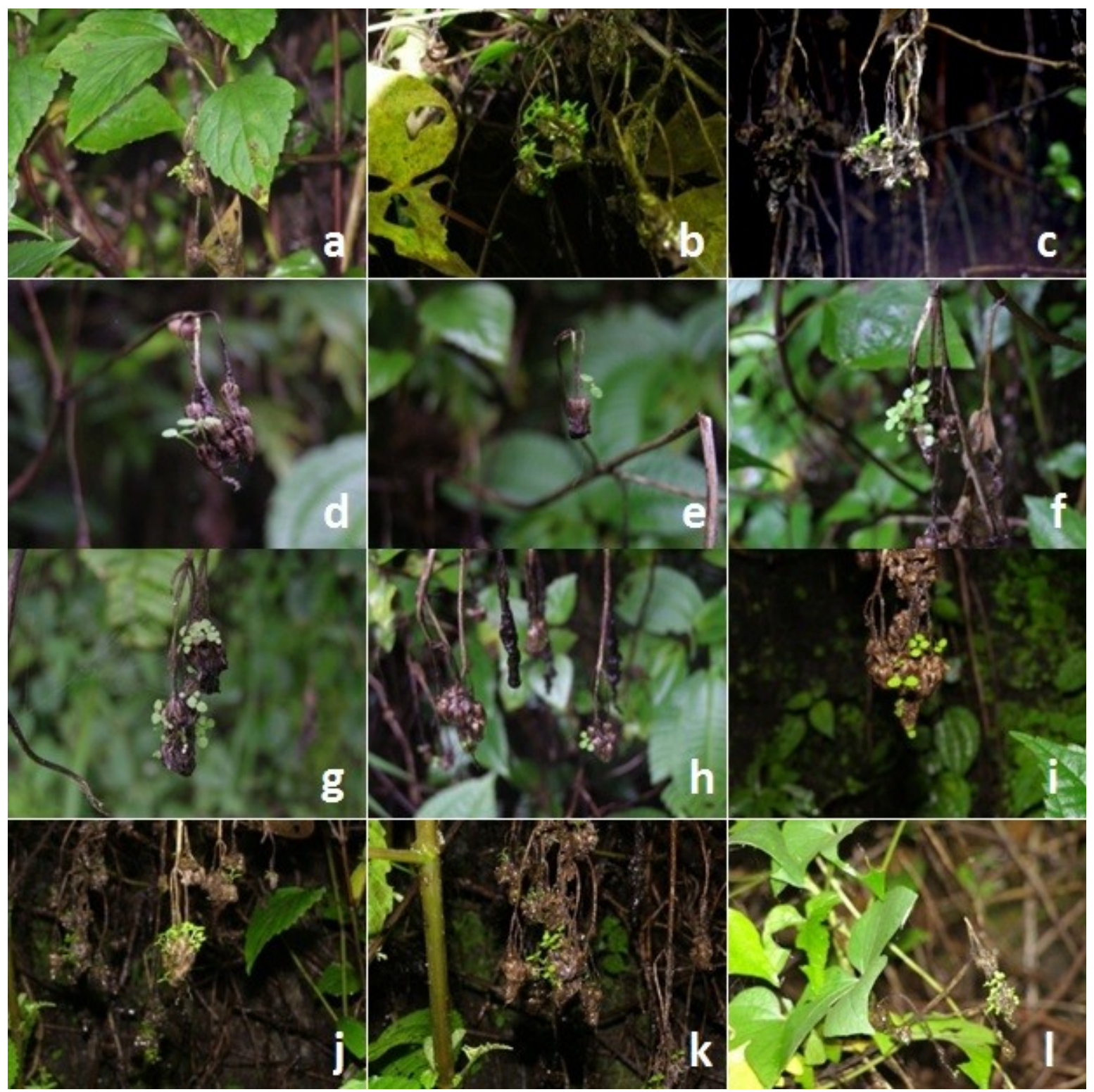

Figure 5: Pictorial evidences of pseudo-viviparous germination in Ageratina adenophora (a-l). Cypsela germinates when it still attached in capitulum, a clump of seedling fallen on lower substratum

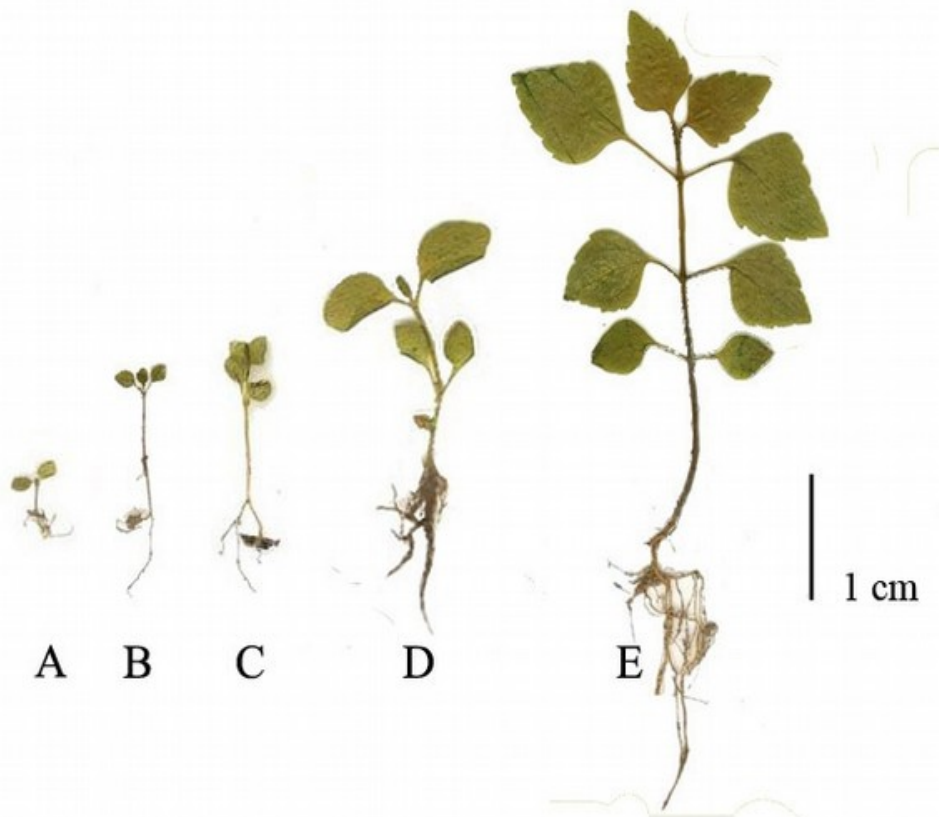

Figure 6: Different stages of seedling development (A-E) of Ageratina adenophora 
parachute mechanism due to lack of effective pappus. This could be attributed to the fact that the plant's tendency to deviate the usual mode of dispersal of its close relatives and a very first step towards formation of dense colony surrounding its own habitat sectors.

\section{Induced pseudo-viviparous germination and single colony formation}

Aggressiveness of the species had also been reflected in its single generation individuals with vigorous growth rate in each colony (Figure 4) at a particular sector of its occurrence. Individuals of each colony mature and flower simultaneously. The clusters of flowers remain attached on the mother plants for significantly long span of time during the period of heavy monsoon. Heavy rain keep the head (capitulum) wet for long time that also prevent cypsela dispersal; on the other hand, cypsela whenever dispersed, cannot spread wide as heavy rain settle them on the ground. Very frequently, the cypsela had been found to get germinated with two minute cotyledons on the receptacle of head, still attached with the mother plant during monsoon (Figure 5). Subsequently, moist heads with many minute green propagules (each with two green protruded paracotyledons) become heavy and drop down entirely on the lower substratum and start to grow with normal series of seedling development (Figure 6). It was the beginning of the colony formation. As mentioned earlier, the incident of protruding cotyledonary body from the inflorescence still attached with the mother plant and emergence of radical only after shedding is called pseudovivipary. It was also observed that contemporary bunches of propagules from one or more adjacent plants contribute to same colony.

The event of vivipary, semi-vivipary or pseudo-vivipary is a regular feature of mangrove plants and also reported from some sea grass (Elmqvist and Cox, 1996), white clover (Majumdar et al., 2004), chayote (Aung et al., 1990), and some members of Cyperaceae (Gordon-Gray et al., 2009) and Poaceae (Kuzmanović et al., 2012; Milton et al., 2008; Vega and Rugolo-de-Agrasar, 2006). In Cyperaceae pseudo-vivipary occurs by the development of plantlets adjacent to inflorescence or a floret within a spikelet (Gordon-Gray et al., 2009). However, it is undoubtedly a striking character in a nonmangrove dicotyledonous Asteraceae member. In Pennisetum setaceum (Fountain grass) pseudo-vivipary is induced by inundation of immature inflorescences when its habitat (Gamka River in the Karoo National Park, South Africa) flooded (Milton et al., 2008). Subsequently, plantlet production facilitates the spread of this species in seasonally flooding rivers in arid regions. Similarly, here Ageratina also gets sufficient moisture to keep the head wet even after fruit maturation driving it towards the pseudo-vivipary. It supports the plants adaptation to higher reproduction rate as well as getting advantage in preventing the huge propagule wastage through fast flowing rainwater of hill slopes till the monsoon rain subside. Hence, the induced pseudo-vivipary in $A$. adenophora of Asteraceae is an adaptive advance trait for greater possibilities of survival of the species and aggressive colony formation.

\section{Conclusion}

Ageratina adenophora, a non-mangrove member from the Asteraceae family, shows a nice pattern of induced pseudo-viviparous germination, as a result of the high monsoon rainfall. By this mode of reproductive strategy clumps of germinating propagules develop on the fully matured heads still attached with the mother plants. Several clumps of such propagules falling on the lower substratum give rise to single generation colonies of more or less same size of individuals. The vigorous growth of the species removes other associated plants from its colonies and makes a dense cover on hill slope reducing the rate of soil erosion as well as chances of land slide.

\section{Author contributions}

All authors have contributed significantly. NCK has observed and documented the feature from natural condition. Both authors have performed the laboratory works and prepared the manuscript.

\section{Acknowledgements}

The present study has been carried out by the authors for their personal interest and the work is not financially supported by any organization. Infrastructure facility was partly provided by Barasat Govt. College. Authors are thankful to the Principal, all faculties and non-academic staffs of Botany department of this college. Reviewers of the article are greatly acknowledged for their tedious effort in reviewing the manuscript.

\section{References}

Akhtar, N., H. Hussain Naqvi, and F. Hussaain. 1978. Biochemical inhibition (allelopathy) exhibited by Cenchrus ciliaris Linn. and Chrysopogon aucheri (Bioss) Stapf. PakJ For 28(4): 194-201.

Aung, L. H., A. Ball, and M. Kushad. 1990. Developmental and nutritional aspects of chayote (Sechium edule, Cucurbitaceae). Economic Botany, 44(2): 157-164. doi: 10.1007/BF02860483

Baniya, A. M. S., and M. D. Bhattarai. 1984. Distribution of Eupatorium adenophorum in some parts of Phulchoki hills and its soil relation. Kathmandu: Amrit Campus. 38 pp. 
Biswas, K. 1934. Distribution of some of the common harmful exotic weeds established in the country. Ind For 60: 861-865.

Calera, M. R., A. L. Anaya and M. Gavilanes-Ruiz. 1995. Effect of phytotoxic resin glycoside on activity of $\mathrm{H}+$-ATPase from plasma membrane. $J$ Chem Ecol 21(3): 289-297. doi: 10.1007/BF02036718

Chettri, M. K. 1986. Effects of herbicides on Eupatorium adenophorum [thesis]. Kathmandu: Central Department of Botany, Tribhuvan University. 61 pp.

Elmqvist, T., and P. A. Cox. 1996. The evolution of vivipary in flowering plants. Oikos 77: 3-9. doi: 10.2307/3545579

Gawronska, H., and A. Golisz. 2006. Allelopathy and biotic stresses. In: Allelopathy - A Physiological Process with Ecological Implications. M. J. Regiosa, N. Pedrol, L. Gonzalez, Springer, Netherlands. pp. 211-227. doi: 10.1007/1-4020-4280-9_10

Gordon-Gray, K. D., H. Baijnath, C. J. Ward, and P. D. Wragg. 2009. Studies in Cyperaceae in southern Africa 42: Pseudo-vivipary in South African Cyperaceae. $S$ Afr J Bot 75(1): 165-171. doi:10.1016/j.sajb.2008.07.012

Inderjit and Duke, S. O. 2003. Ecophysiological aspects of allelopathy. Planta, 217(4): 529-539. doi: 10.1007/s00425-003-1054-Z

Ismail, F. A., L. M. Nitsch, M. M. Wolters-Arts, C. Mariani, and J. W. Derksen. 2010. Semi-viviparous embryo development and dehydrin expression in the mangrove Rhizophora mucronata Lam. Sex Plant Reprod 23(2): 95-103. doi: 10.1007/s00497-0090127-y

Kunwar, R. M., V. N. G. Gupta, O. R. Vetaas, and Chaudhary. 2000. Vegetation dynamics of herbaceous plants in lower Arun river basin of Makalu Barun buffer zone, east Nepal. In: Proceeding of the international symposium on the Himalayan environments: Mountain sciences and ecotourism/biodiversity. Kathmandu. Kathmandu Hokkaido University. Tribhuvan University and the United Nations University. pp. 24-26.

Kuzmanović, N., P. Comanescu, and D. Lakušić. 2012. First record of vivipary in a species of the genus Sesleria (Poaceae). Botanica Serbica 36(2): 111115.

Majumdar, S., S. Banerjee, and K. K. De. 2004. Vivipary in white clover (Trifolium repens L.). Current Science 86(1): 29-30.
Milton, S. J., W. R. J. Dean, and S. J. Rahlao. 2008. Evidence for induced pseudo-vivipary in Pennisetum setaceum (Fountain grass) invading a dry river, arid Karoo, South Africa. S Afr J Bot 74(2): 348-349. doi:10.1016/j.sajb.2007.11.012

NSW (New South Wales) noxious weed act, 1993.

Priestley, J. H. 1913. The quadrat as a method for the field excursion. $J$ Ecol 1(2): 89-94. doi: $10.2307 / 2255667$

Putnam, A. R., and W. B. Duke. 1978. Allelopathy in agroecosystems. Ann Rev Phytopathol 16(1): 431451. doi: 10.1146/annurev.py.16.090178.002243

Qu, Y., Z. Xiao, G. Zhou, X. Liang, and X. Li. 2011. Mapping the distribution of Crofton weed (Eupatorium adenophorum spreng) in southwest of China using time series remote sensing data. In: Geoscience and Remote Sensing Symposium (IGARSS), 2011 IEEE International (pp. 660-663). IEEE. doi: 10.1109/IGARSS.2011.6049216

Rai, J. P. N., and R. S. Tripathi. 1982. Allelopathy as a factor contributing to dominance of Eupatorium riparium Regel [perennial weed species of family Asterace]. Ind J Ecol 9: 14-20.

Reigosa, M. J., N. Pedrol, and L. González. 2006. Allelopathy: a physiological process with ecological implications. Springer Science \& Business Media, Netherlands.

Richardson, D. M., P. A. Williams, and R. J. Hobbs. 1994. Pine invasions in the Southern Hemisphere: determinants of spread and invadability. $J$ Biogeogr 21(5): 511-527. doi: 10.2307/2845655

Tripathi, R. S., R. S. Singh, and J. P. N. Rai. 1981. Allelopathic potential of Eupatorium adenophorum, a dominant ruderal weed of Meghalaya. In: Proceedings of Indian Academy of Sciences 47(3): 458-465.

Vega, A. S., and Z. E. Rugolo-de-Agrasar. 2006. Vivipary and pseudovivipary in the Poaceae, including the first record of pseudovivipary in Digitaria (Panicoideae: Paniceae). S Afr J Bot 72(4): 559-564. doi:10.1016/j.sajb.2006.03.012

Whittaker, R. H. 1971. The chemistry of communities. In: Biochemical interactions among plants, pp.10-18.

Yan, X., L. Zhenyu, W. P. Gregg, and L. Dianmo. 2001. Invasive species in China - an overview. Biodiver Conserv 10(8): 1317-1341. doi: 10.1023/A:1016695609745. 